\title{
Konstitusi dan Hak Asasi Manusia
}

\author{
Bagir Manan* dan Susi Dwi Harijanti**
}

\begin{abstract}
Abstrak
Salah satu titik sentral dalam konstitusionalisme adalah persoalan hak asasi manusia. Dalam kaitan ini, konstitusi memiliki peran penting yang bukan hanya sekadar melakukan jaminan dan proteksi secara tertulis, melainkan pula menyediakan berbagai nilai yang digunakan oleh lembaga peradilan dalam interpretasi serta elaborasi hak-hak tersebut. Artikel ini menjelaskan hubungan antara konstitusi dan hak asasi manusia, yang mencakup persoalan isi dan pengertian hak asasi manusia, tempat hak asasi manusia dalam konstitusi, termasuk dalam UUD 1945, serta akibat pengaturan hak asasi manusia dalam konstitusi. Artikel ini menegaskan bahwa penempatan hak asasi manusia dalam konstitusi tidak semata-mata menjadikannya sebagai hak-hak fundamental yang bersifat mendasar, melainkan pula sebagai hak-hak konstitusional yang tertinggi.
\end{abstract}

Kata Kunci: hak asasi manusia, hak konstitusional, konstitusi, konstitusionalisme, UUD 1945.

\begin{abstract}
One of the central points on constitutionalism is the idea of human rights. Constitution plays a major role by not only inserting human rights articles in aiming to secure and protect these rights, but also providing fundamental values that are used by Court in interpreting and elaborating such rights. This article discusses the relationship between a constitution and human rights, including issues of the meaning and content of human rights, position of human rights in a constitution (including the 1945 Amended Constitution), as well as consequences of inserting human rights norms into a constitution. It is argued that the entrenchment of human rights in a constitutional document does not only give them status as fundamental or basic rights, but it also provides stronger position as the supreme constitutional rights.
\end{abstract}

Constitution and Human Rights

Keywords: human right, constitutional rights, constitution, constitutionalism, the 1945 Amended Constitution.

\section{A. Pendahuluan}

Konstitusi dalam tulisan ini adalah konstitusi dalam arti sempit, yakni konstitusi yang terdokumentasi yang sering disebut sebagai undang-undang dasar. ${ }^{1}$ Hampir di

PADJADJARAN Jurnal IImu Hukum Volume 3 Nomor 3 Tahun 2016 [ISSN 2460-1543] [e-ISSN 2442-9325]

* Guru Besar Tidak Tetap Fakultas Hukum Universitas Padjadjaran, Jl. Dipati Ukur 35 Bandung, S.H. (Universitas Padjadjaran), M.CL (Southern Methodist University), Dr. (Universitas Padjadjaran).

** Dosen Fakultas Hukum Universitas Padjadjaran, Jl. Dipati Ukur 35 Bandung, sdharijanti@gmail.com, S.H. (Universitas Padjadjaran), LL.M., Ph.D. (University of Melbourne).

$1 \quad$ Lihat C.F. Strong, Modern Political Constitution, London: Sidgwick \& Jackson, 1966 dan K.C. Wheare, Modern Constitution, Oxford: Oxford University Press, 1960. 
seluruh negara, konstitusi yang memuat berbagai materi muatan, termasuk kaidah-kaidah tentang Hak Asasi Manusia (HAM), ditempatkan sebagai peraturan tertinggi atau "high-ranking regulatory law, a 'statute' fraught with direct legal consequences". ${ }^{2}$ Namun demikian, konstitusi tidaklah diartikan sesederhana itu karena konstitusi mengandung pula makna yang lebih filosofis. ${ }^{3}$ Frank I. Michelman, misalnya, mengatakan konstitusi lebih dari sekedar hukum positif, yakni "a mirror reflecting the national soul, perhaps; an expression of national ideals, aspirations, and values expected, as such, to preside and permeate the process of judicial interpretation and judicial discretion throughout the length and breadth of the national legal order". ${ }^{4}$ Salah satu materi muatan utama dari konstitusi adalah HAM.

Dalam praktik, konstitusi setiap negara mengatur HAM dengan menggunakan sistematika yang berbeda. Amerika Serikat, misalnya, ketentuan mengenai HAM ditemukan dalam Amandemen ke-I hingga X yang dikatakan sebagai Bill of Rights. Umumnya konstitusi yang dihasilkan sebagai produk perubahan rezim kekuasaan mengatur HAM dalam bab tersendiri, sebagaimana dijumpai misalnya di Filipina ${ }^{5}$ dan Afrika Selatan. ${ }^{6} \mathrm{Hal}$ serupa terjadi pula di Indonesia melalui Perubahan Kedua Undang-Undang Dasar 1945 (UUD 1945). Konstitusi Australia tidak memiliki bab khusus mengenai HAM, melainkan tersebar dalam beberapa pasal. ${ }^{7}$ India menjadi salah satu contoh menarik di mana norma-norma HAM selain terdapat dalam bab khusus, diatur pula dalam Bab 'Directive Principles'. ${ }^{8}$

Dalam kenyataan, sering terdapat kesenjangan (gap) antara 'das Sollen' dan 'das Sein'. Sebagai 'das Sollen', konstitusi cq UUD biasanya memuat berbagai asas dan norma konstitusionalisme, negara hukum, demokrasi, serta perlindungan dan jaminan HAM. Tetapi tidak demikian dalam tataran 'das Sein' atau kenyataan. Dapat terjadi UUD memuat dengan lengkap aneka ragam HAM. Namun dalam kenyataan, ketentuan-ketentuan tersebut bukan saja tidak dijalankan, bahkan ada berbagai pembatasan dan penindasan, serta kemiskinan dan keterbelakangan.

2 Frank I. Michelman, “The constitution, social rights, and liberal political justification", I.CON, Vol. 1, No. 1, 2003, hIm. 13 .

3 Lihat antara lain, Bagir Manan dan Susi Dwi Harijanti, Memahami Konstitusi: Makna dan Aktualisasi, Jakarta: Rajagrafindo Persada, 2014.

4 Frank I. Michelman, Loc.cit.

Bab III Konstitusi Filipina 1987.

Bab III Konstitusi Afrika Selatan 1996.

Konstitusi Australia: $s 41$ - the right to vote; $s 51(x x x i)$ - the right not to have the Commonwealth acquire property, except on just terms; $s 80$ - the right to trial by jury; 592 - the right that 'trade, commerce, and intercourse among the States, whether by means of internal carriage or ocean navigation, shall be absolutely free'; 116 - the right to freedom of religion; and s 117-the right to freedom from disabilities or discrimination on the basis of State residence.

8 Bagian III "Fundamental Rights" dan Bagian IV “Directive Principles". Misalnya, Pasal 41 yang mengatur hak atas pekerjaan, hak atas pendidikan, dan mendapatkan bantuan sosial dalam kondisi-kondisi tertentu (the rights to work, to education and to have social assistance in certain cases). 
Berdasarkan kenyataan tersebut, Walter F. Murphy mengemukakan 3 (tiga) jenis konstitusi, yaitu: ${ }^{9}$

1. Konstitusi pura-pura (sham constitution). Artinya, konstitusi ada, tetapi sebenarnya tidak ada. Negara dijalankan semata-mata oleh perorangan atau kelompok kecil yang sewenang-wenang;

2. Konstitusi kosmetik, yang berarti konstitusi hanyalah sekedar alat pajangan, tidak berfungsi sesuai dengan makna dan fungsi konstitusi; dan

3. Konstitusi yang sebenarnya, dalam arti berjalan dan dijalankan sebagaimana mestinya.

Artikel ini menjelaskan hubungan antara konstitusi dengan HAM melalui beberapa pertanyaan mendasar, yakni: pertama, mengapa HAM perlu diatur dalam konstitusi dan kedua, apa makna pengaturannya dan apa akibat hukum pengaturan tersebut. Untuk menjawab beberapa masalah tersebut, artikel ini terbagi menjadi 5 (lima) bagian. Setelah Bagian Pendahuluan, uraian dalam Bagian B menjelaskan isi dan pengertian hak asasi manusia, yang dilanjutkan dengan paparan mengenai tempat hak asasi manusia dalam konstitusi pada Bagian C. Uraian mengenai hak asasi manusia dalam UUD 1945 terdapat dalam Bagian D, serta Penutup yang disampaikan dalam Bagian E.

\section{B. Pengertian dan Isi Hak Asasi Manusia}

John Locke disebut sebagai bapak hak asasi manusia. Teori perjanjian John Locke menjadi dasar negara dengan kekuasaan terbatas. Menurut Locke, meskipun ada perjanjian membentuk satu kesatuan masyarakat atau negara, rakyat tetap memiliki hak alamiah (natural rights) sebagai inalienable rights. Negara atau pemerintah tidak boleh mengganggu atau merampas hak-hak alamiah, yaitu life, liberty, property sebagaimana disampaikan oleh John Locke dalam buku Two Treaties of Civil Government:

"But though men when they enter into society give up the equality, liberty, and executive power they had in the state of Nature into the hands of society, to be so far disposed of by the legislative as the good society shall require, yet it being only with the intention in everyone the better preserve himself, his liberty and property, ... the power of the society or legislative constitute by them can never be supposed to extend further than the common good but is obliged to secure everyone's property by providing against those three defects above mentioned that made the state of Nature an uneasy".10

9 Vicky C. Jackson dan Mark Tushnet, Comparative Constitutional Law, New York: Foundation Press, 1999, hlm. 195-196.

10 Clarence Morris (eds), The Great Legal Philosophers, Philadelphia: University of Pennsylvania Press, 1979, hlm. 152. 
Teori perjanjian Locke berbeda dengan teori perjanjian Hobbes dan Rousseau. Hobbes menggambarkan peri kehidupan sebelum ada perjanjian membentuk negara (state of nature) adalah kehidupan yang kacau balau tidak ada ketentraman dan keamanan, yang digambarkan sebagai homo homini lupus bellum omnium contra omnes, all against all (Leviathan): "..., that during them all in war, they in a condition which is called warre; and such a warre, us is every man, against every man". ${ }^{11}$ Sebaliknya, Locke menggambarkan state of nature itu suatu peri kehidupan surgawi. Setiap orang mengetahui hak dan kewajibannya terhadap orang lain. Hak seseorang dibatasi oleh hak orang lain. Tetapi kehidupan alamiah surgawi ini mengandung ancaman kekacauan. Menurut Locke, akhirnya manusia itu sangat mencintai diri dan kelompoknya yang akan menimbulkan perselisihan dengan orang atau kelompok lain. Perbedaan lain atas dasar prinsip inalienable rights yang tetap ada pada rakyat, Locke mengkonsepsikan sebagai dasar the limited government (negara dengan kekuasaan terbatas).

Pandangan berbeda disampaikan oleh Thomas Hobbes. Rakyat menurut Hobbes menyerahkan semua hak dan kebebasannya kepada primus inter paris yang berkuasa secara mutlak. Teori perjanjian Hobbes menjadi pembenaran absolutisme dan sistem kekuasaan otoriter. Sebenarnya ajaran otoritarian didapati juga dalam ajaran lain seperti Machiavelli (The Prince). Bagaimana dengan Rosseau? Walaupun ada kontrak sosial, kekuasaan negara cq pembentukan undang-undang dilaksanakan berdasarkan volenté generale atau general will. Inilah dasar konsep kedaulatan rakyat. Ada kritik terhadap konsep volenté general, yaitu dapat melahirkan tirani mayoritas yang menindas minoritas.

Perbedaan lain, Rousseau menolak sistem hak milik pribadi, sedangkan Locke memandang hak milik pribadi merupakan salah satu hak asasi. Menurut Rousseau, hak milik pribadi merupakan sumber kegaduhan. Di masa klasik, penolakan terhadap sistem hak milik pribadi didapati juga pada ajaran Plato. Ada pula beberapa pemikir lain yang menolak sistem hak milik pribadi dan yang paling terkenal adalah Karl Marx (Marxisme). Menurut Marx, hak milik pribadi melahirkan sistem kelas dalam masyarakat, yaitu kelas pemilik modal (kapitalis) dan kelas

\footnotetext{
“Meskipun pada saat sepakat membentuk satu masyarakat (negara), manusia menyerahkan kepada masyarakat (negara) hak-hak atas persamaan, kebebasan, dan hak melaksanakan sendiri kekuasaan, untuk diatur badan legislatif sebagai syarat kehidupan masyarakat yang baik, tetapi itu, semata-mata dengan maksud agar setiap orang dapat secara lebih melindungi diri, kebebasan dan harta benda mereka, ... kekuasaan masyarakat (negara) atau badan legislatif yang mereka bentuk tidak boleh mengatur sehingga melampaui tujuan demi kebaikan bersama, melainkan diwajibkan untuk menjamin hak milik setiap orang dengan cara-cara meniadakan kelemahan yang menyebabkan kehadiran masyarakat alamiah menjadi tidak mudah (tidak nyaman)."

$11 \quad$ Ibid., hlm. 110. "Dalam zaman ketika manusia hidup tanpa ada kekuasaan bersama untuk menjamin manusia saling menghormati, mereka ada dalam suasana perang, dan perang itu adalah setiap orang berperang melawan setiap orang lain (semua lawan semua)."
} 
buruh (proletar). Sistem hak milik bermuara pada kekuasaan kapitalis yang menguasai alat-alat produksi dan menindas kaum proletar (buruh). Hanya ada satu cara meniadakan penindasan, yaitu meniadakan kelas (membentuk masyarakat tanpa kelas) dengan revolusi dan meniadakan sistem hak milik perorangan dan meniadakan penguasaan alat produksi oleh kelas tertentu (kapitalis). Masyarakat tanpa kelas itulah yang disebut masyarakat komunis yang menuju pada peniadaan negara. Jadi sepanjang mengenai eksistensi negara, Marxisme merupakan kebalikan dari teori perjanjian (Hobbes, Locke, dan Rousseau).

Berkenaan dengan penggolongan hak asasi, Vicky Jackson dan Mark Tushnet menjelaskan: ${ }^{12}$

1) Hak asasi generasi pertama, yaitu 'individual and political rights', meliputi:

a) Freedom of expression: Freedom of expression mencakup, antara lain, freedom of press, freedom of opinion, dan freedom of association.

b) Freedom of religion: Apabila dikaitkan dengan 'The First Ten Amendments' UUD Amerika Serikat (1791), freedom of religion merupakan salah satu wujud freedom of expression yang dikenal dengan sebutan 'establishment clause'.

c) Non discrimination (freedom from discrimination): Wujud dari freedom from discrimination, antara lain, lahir prinsip 'equality before the law', larangan segala bentuk perbudakan dan peruluran (non slavery), eksploitasi manusia oleh manusia (exploitation de l'Homme par I'Homme). Dalam kaitan ini perlu dicatat 'State of Union' di hadapan Congress tahun 1941 yang dikenal dengan sebutan 'Four Freedom Roosevelt', yaitu:

i. Freedom of speech and expression (kebebasan berbicara dan berekspresi);

ii. Freedom of worship (kebebasan beragama);

iii. Freedom from want (bebas dari kemiskinan);

iv. Freedom from fear (bebas dari rasa takut).

2) Hak asasi generasi kedua, yaitu 'social and economic rights'.

Vicky Jackson dan Mark Tushnet menyebutnya sebagai 'social welfare rights'. Paham hak asasi ini mulai berkembang abad ke-19 yang dipengaruhi oleh kebangkitan 'Social Democratic Parties' yang mengusung perjuangan kesejahteraan kaum buruh. Gagasan dan perjuangan partai-partai demokrasi sosial ini direspon, antara lain oleh Otto von Bismark (Perdana Menteri Jerman) dengan membentuk beberapa institusi kesejahteraan sosial. Respon lain yaitu keluarnya 'Rerum Novarum' 1891. ${ }^{13}$ Selain menyampaikan 4 (empat) jenis kebebasan di atas,

$12 \quad$ Ibid., hlm. 1436.

13 Rerum Novarum yang berarti 'Perubahan secara revolusioner' merupakan sebuah surat yang dibuat oleh Paus 
Roosevelt juga menyampaikan lima hak asasi sosial ekonomi dalam 'State of Union' 1941, yaitu:

a) The right to earn enough to provide adequate food and clothing and recreation' (hak atas pendapatan yang cukup untuk secara layak membeli pangan dan sandang serta untuk berekreasi);

b) The right to adequate medical care' (hak untuk mendapat pelayanan kesehatan yang layak);

c) The right to decent home' (hak atas rumah yang layak);

d) The right to good education' (hak atas pendidikan yang baik);

e) The right to adequate protection from economic fears of old age, sickness, accident, and unemployment' (hak mendapatkan perlindungan yang cukup menghadapi persoalan ekonomi bagi manusia lanjut usia, sakit, kecelakaan, dan ketika menganggur).

3) Hak asasi generasi ketiga yang memberikan jaminan atas hak-hak budaya, terutama hak-hak kelompok minoritas dan perlindungan lingkungan.

Roy Gregory dan Philip Giddings melanjutkan klasifikasi di atas dengan mengkategorikan 3 (tiga) generasi tersebut dalam kategori pertama yang disebut substantive right dan kategori kedua disebut procedural rights. ${ }^{14}$ Hak prosedural berkaitan dengan peran negara dalam melaksanakan pelayanan publik, sehingga melahirkan pemikiran untuk mengarusutamakan pelayanan publik sebagai bagian dari HAM. ${ }^{15}$

Kembali pada 5 (lima) hak asasi ekonomi sosial sebagaimana disampaikan Roosevelt di atas, lazim disebut sebagai 'The Second Bill of Rights', sedangkan The First Bill of Human Rights dimuat dalam 'The First Ten Amendments' (1791) yang dikenal juga dengan sebutan 'Bill of Rights Amendment'. Walaupun tidak semuanya, tetapi sebagian besar materi dalam Sepuluh Amandemen Pertama (I-X) berisi atau mengatur HAM, yaitu:

a. Amandemen ke-I mengatur: Kongres tidak akan (dilarang) membuat undangundang mengenai kebebasan beragama (establishment of religion) atau melarang kebebasan menjalankan agama (prohibiting the free exercise thereof),

Leo XIII pada tanggal 15 Mei 1891 yang berisikan kondisi para pekerja atau kaum buruh saat itu. Surat Paus Leo tersebut ditujukan kepada seluruh pemimpin gereja Katolik. Surat itu membahas hubungan serta kewajiban yang bersifat timbal balik antara kaum buruh dan pemilik modal serta hubungan antara negara atau pemerintah dengan warga negaranya, serta mendukung para buruh membentuk serikat pekerja. Di satu pihak, Rerum Novarum menolak sosialisme dan kapitalisme yang tidak terbatas, namun di pihak lain mendukung hak milik perorangan, dalam Wikipedia, "Rerum Novarum", https://en.wikipedia.org/wiki/Rerum novarum, diakses 20 Maret 2017.

14 Bellamy, Richard, dan Alex Warleigh (eds), Citizenship and Governance in the European Union, London, New York: Continuum, 2001, hlm. 73.

15 Atip Latipulhayat, "Editorial: Pengarusutamaan Pelayanan Publik sebagai HAM", Padjadjaran Jurnal IImu Hukum, Vol. 1, No. 2, 2014, hlm. i-iv. 
membatasi kebebasan berbicara atau membatasi kebebasan pers, kebebasan rakyat untuk berapat dan berkumpul secara damai, dan hak atas kebebasan menyampaikan petisi kepada pemerintah untuk menuntut suatu kerugian (abridging the freedom of speech, or of the press, or the right of the people peacefully to assembly, and to petition the government for a redress of grievances);

b. Amandemen ke-IV yang mengatur hak rakyat atas keamanan (perlindungan) diri pribadi, rumah, surat-surat, dan harta benda tidak boleh dilanggar dengan melakukan penggeledahan dan penyitaan tanpa alasan yang cukup. Tidak dibenarkan mengeluarkan perintah (penyelidikan, penyidikan, penggeledahan, dan penyitaan) tanpa alasan yang cukup (probable cause) yang dilakukan di bawah sumpah atau persetujuan dengan menunjuk tempat yang akan digeledah dan orang-orang atau barang-barang yang akan disita;

c. Amandemen ke-V:

Terdapat beberapa ketentuan tentang hak asasi:

1) Tidak seorangpun dapat dipaksa menjawab pertanyaan (karena disangka melakukan) suatu kejahatan, kecuali di hadapan 'grand jury';

2) Tidak seorangpun dapat diperiksa 2 (dua) kali atas perkara yang sama yang akan membahayakan nyawa atau sebagian anggota badan;

3) Tidak seorangpun dapat diperiksa menjadi saksi melawan dirinya sendiri, atau mengancam nyawa, kebebasan dan harta bendanya tanpa suatu proses hukum;

4) Dilarang mencabut atau mengambil hak milik pribadi untuk kepentingan umum tanpa ganti rugi yang wajar.

d. Amandemen ke-VI: Terdakwa berhak atas peradilan yang terbuka dan cepat, diadili oleh juri yang tidak memihak (impartial), berdasarkan hukum yang sudah ada, dan kepada terdakwa disampaikan perbuatan dan alasan-alasannya dengan menghadirkan saksi-saksi yang melawannya, dan saksi-saksi yang meringankan, serta didampingi penasihat hukum;

e. Amandemen ke-VII yang mengatur hak untuk diadili oleh juri (sengketa yang bernilai lebih dari 20 (dua puluh) dolar; dan

f. Amandemen ke-VIII yang menetapkan larangan uang jaminan (bail) serta denda yang berlebihan, serta larangan penghukuman yang keji dan luar biasa.

Selain atas dasar amandemen-amendemen di atas, pengaturan hak asasi manusia dijumpai pula dalam amandemen-amandemen lain, seperti:

a. Amandemen ke-XIV (1868) yang mengatur, antara lain: negara bagian dilarang membuat atau menegakkan hukum yang membatasi hak-hak istimewa serta imunitas warga negara Amerika Serikat, tidak dibenarkan negara bagian merampas nyawa, kebebasan, dan harta bendanya tanpa melalui satu proses 
hukum yang layak dan benar (due process of law), ataupun meniadakan perlindungan hukum;

b. Amandemen ke-XV (1870) yang menentukan hak pilih warga negara tidak boleh dicabut atau dibatasi atas dasar ras, warna kulit, dan perbudakan di masa lalu;

c. Amandemen ke-XIX (1920) yang mengatur hak pilih warga negara tidak boleh dicabut atau dibatasi atas dasar perbedaan jenis kelamin; dan

d. Amandemen ke-XXIV (1964) yang mengatur hak pilih warga negara tidak boleh dibatasi atau dicabut karena alasan tidak (belum) membayar pajak.

\section{Tempat Hak Asasi dalam Konstitusi}

Di atas telah dicatat berbagai Amandemen UUD Amerika Serikat yang memuat hakhak asasi. Pada saat ini, dapat dipastikan tidak ada UUD yang tidak memuat aneka ragam hak asasi. Hak asasi menjadi suatu objek yang harus ada dan dimuat dalam UUD. Negara-negara yang tidak memiliki UUD (Inggris, Israel, Selandia Baru) pasti mempunyai kumpulan kaidah tentang hak asasi, baik yang diatur dalam undangundang atau karena keterikatan dalam suatu perhimpunan atau hubungan internasional.

Selain Magna Carta (1215), Bill of Rights (1688), Inggris mempunyai undangundang khusus tentang hak asasi, yaitu Human Rights Act 1998. Selain itu, sebagai anggota Perserikatan Bangsa-Bangsa (PBB), Inggris juga terikat pada ketentuanketentuan hak asasi dalam Universal Declaration of Human Rights 1948 dan beberapa konvensi PBB di bidang hak asasi, misalnya International Covenant on Civil and Political Rights (ICCPR), International Covenant on Economic, Social and Cultural Rights (ICESCR) tahun 1966, serta konvensi-konvensi lainnya. Demikian pula Selandia Baru, dan semestinya Israel.

Di Indonesia, salah satu alasan mengubah UUD 1945 karena adanya kehendak melengkapi ketentuan-ketentuan tentang hak asasi. Sebelum perubahan, ketentuan mengenai HAM dalam UUD 1945 telah mencerminkan secara sederhana hak asasi klasik sebagaimana dijumpai dalam Pasal 28 dan Pasal 29, dan hak asasi sosial-ekonomi (subsistence rights) seperti dimuat dalam Pasal 33 dan Pasal 34. Selain itu, struktur HAM dalam UUD 1945 memuat pula kewajiban seperti diatur dalam Pasal 30. Namun demikian, apabila dibandingkan dengan ketentuan hak asasi yang pernah dimuat dalam Konstitusi Republik Indonesia Serikat 1949-1950 (KRIS) dan UUD Sementara 1950 (UUDS), muatan HAM dalam UUD 1945 sangat terbatas. Dalam praktik di berbagai negara, UUD umumnya memuat secara lengkap hak asasi sebagai sub-sistem paham negara konstitusional demokratik dan berdasarkan atas hukum. ${ }^{16}$

16 Lihat, Bagir Manan, Teori dan Politik Konstitusi, Yogyakarta: FH UII Press, 2002. 
Perubahan materi muatan HAM dalam Perubahan UUD 1945 terlihat masif, karena UUD 1945 sebelum perubahan tidak memuat rincian hak-hak asasi manusia. Dalam berbagai tulisan para ahli dinyatakan bahwa penambahan rincian tersebut dilakukan dengan cara memasukkan berbagai hak yang dimuat dalam Deklarasi Universal Hak Asasi Manusia (Universal Declaration of Human Rights) 1948. ${ }^{17}$ Penambahan ini sekaligus memperlihatkan respons Indonesia terhadap tuntutan adanya perlindungan HAM melalui proteksi konstitusi (constitutional protection) guna memperkuat konstitusionalisme di Indonesia.

Mengapa ketentuan-ketentuan tentang hak asasi sudah semestinya dimuat dalam UUD? Dengan cara itu, hak asasi tidak sekadar sebagai natural rights, tidak sekadar sebagai legal rights, melainkan sekaligus sebagai constitutional rights. Bahkan secara tegas, Frank I. Michelman menyatakan "...by naming something a constitutional right you also name it a legal rights and so...make the judiciary responsible for its effectuation". ${ }^{18}$ Selain itu, konstitusi juga memiliki fungsi tersendiri.

Menurut Murphy, terdapat 4 (empat) fungsi konstitusi yang meliputi: ${ }^{19}$ Pertama, konstitusi dapat sekadar sebagai kepura-puraan, sebagai kosmetik atau benar-benar sebagai realitas. Murphy menyebut 2 (dua) contoh konstitusi semacam ini, yaitu Konstitusi Stalin dan Konstitusi Mao. Kedua, sebagai 'a Charter for Government' (Piagam Pemerintahan), konstitusi berfungsi menentukan dasar fundamental susunan pemerintahan yang dibenarkan oleh hukum. Ketiga, sebagai 'Guardian of Fundamental Rights' (Pelindung Hak-Hak Fundamental/Hak-Hak Dasar). Ukuran yang dipergunakan adalah sampai sejauh mana suatu konstitusi bersandar atau memuat prinsip-prinsip, teori-teori demokrasi, dan teori-teori konstitusi. Konstitusi yang memuat prinsip-prinsip demokrasi dan konstitusionalisme akan melindungi hak-hak partisipasi politik dan hak-hak substantif dari pembatasan-pembatasan kebebasan rakyat memilih wakil-wakil mereka. Keempat, sebagai 'Covenant, Symbol, and Aspiration' (Konstitusi sebagai suatu perikatan, simbol dan aspirasi).

Dari 4 (empat) fungsi di atas, fungsi konstitusi sebagai 'guardian offundamental rights' yang langsung berkaitan dengan jaminan dan perlindungan hak asasi. Jaminan dan perlindungan hak asasi dapat dilakukan secara langsung dan tidak langsung. Secara langsung yaitu dengan cara memasukkan (incorporate) berbagai hak asasi ke dalam batang tubuh konstitusi.

17 Lihat, Tim Lindsey, "Constitutional reform in Indonesia: Muddling towards democracy" dalam buku Indonesia: Law and Society, $2^{\text {nd }}$ edition, yang disusun oleh Tim Lindsey (eds), Annandale NSW: The Federation Press, 2008, hlm. 29.

18 Frank I. Michelman, Op.cit., hlm 19.

19 Ibid. 
Mendudukkan hak asasi sebagai constitusional right dan untuk menjalankan fungsi penjaganya menjadi alasan negara-negara memberi tempat pengaturan HAM dalam konstitusi. Salah satu negara yang secara masif memasukkan ketentuan hak asasi dalam konstitusinya adalah Afrika Selatan. Sebagai sebuah bangsa yang pernah mengalami sejarah kelam pelanggaran HAM sebagai akibat diberlakukannya politik apartheid, tidak mengherankan jika dalam proses demokratisasi, bangsa Afrika Selatan memutuskan pentingnya pengaturan komprehensif mengenai pemajuan, perlindungan, dan pemenuhan HAM dalam sebuah bab tersendiri, yang kemudian dikenal sebagai Bill of Rights yang terdapat dalam Bab III Konstitusi Afrika Selatan 1996.

Bill of Rights oleh Konstitusi Afrika Selatan 1996 dideskripsikan sebagai 'a cornerstone of democracy in South Africa' ${ }^{20}$ Ketentuan-ketentuan HAM tersebut dipandang merepresentasikan 'a decisive break' dengan pemikiran-pemikiran ataupun praktik-praktik ketatanegaraan masa lalu ${ }^{21}$ yang menandai suatu perjalanan baru bangsa Afrika Selatan. Suatu pendapat yang sejalan dengan pandangan K.C. Wheare mengenai pentingnya sebuah konstitusi bagi suatu negara yaitu 'the desire to make a fresh start' ${ }^{22}$

Pengaturan HAM dalam Konstitusi Afrika Selatan dibagi menjadi aturan-aturan mengenai hak yang termuat dalam 27 pasal dan aturan-aturan operasionalisasi hak-hak tersebut dalam 6 pasal. ${ }^{23}$ Ketentuan-ketentuan operasionalisasi memuat aturan mengenai cara-cara Bill of Rights dilaksanakan, termasuk cara-cara pengadilan menegakkannya. Pasal 7 menegaskan aturan mengenai tanggung jawab negara untuk melakukan pemajuan, perlindungan, dan pemenuhan HAM. Pasal 8 menentukan aplikasi Bill of Rights, sedangkan Pasal 36 mengatur pembatasan HAM.

Penundaan (suspension) HAM saat negara dalam keadaan darurat diatur dalam Pasal 37. Ketentuan mengenai standing untuk penegakan HAM ada dalam Pasal 38. Selanjutnya, Pasal 39 berisi ketentuan mengenai interpretasi terhadap Bill of Rights. Selain keenam pasal yang mengatur operasionalisasi, penegakan HAM juga dikaitkan dengan Bab 8 yang berisi ketentuan-ketentuan penting tentang yurisdiksi pengadilan untuk perkara-perkara ketatanegaraan atau konstitusi, termasuk pemulihan-pemulihan yang dapat ditetapkan oleh pengadilan saat ketentuan Bill of Rights dilanggar. ${ }^{24}$

\footnotetext{
Pasal 7 ayat (1) Konstitusi Afrika Selatan 1996.

21 Iain Currie dan Johan de Waal (eds), The New Constitutional \& Administrative Law, Lansdowne: Juta Academic, 2001, hlm. 319.

2 K.C. Wheare, Op.cit., hlm. 9.

23 lain Curie dan Johan de Waal (eds), Op.cit., hlm. 320.

24 Ibid.
} 
Sebagaimana telah disebutkan di atas, ketentuan-ketentuan HAM substantif dijumpai dalam 27 pasal yang meliputi HAM generasi pertama, kedua, dan ketiga. Hak atas persamaan (equality right) diatur dalam Pasal 9 yang terdiri atas 5 ayat, meliputi prinsip: persamaan di muka hukum; tindakan afirmasi; larangan diskriminasi baik langsung maupun tidak langsung atas dasar antara lain: ras, agama, suku, bahasa, kelahiran, status perkawinan, orientasi seksual, kehamilan, gender; larangan diskriminasi pada tingkat horizontal; dan praduga bahwa diskriminasi atas dasar beberapa alasan yang telah diatur adalah tidak adil, kecuali hukum menentukan lain.

Pasal 10 mengatur martabat manusia (human dignity). Mahkamah Konstitusi Afrika Selatan menyatakan martabat manusia ini bukan hanya bersifat justiciable dan enforceable yang harus dihormati dan dilindungi, melainkan pula sebagai sebuah nilai (value) yang digunakan dalam interpretasi seluruh hak fundamental. ${ }^{25}$ Dalam kaitan dengan Pasal 36 yang memungkinkan adanya pembatasan hak (dikenal sebagai 'balancing right'), pertanyaan yang harus dijawab adalah sampai sejauh mana pembatasan tersebut berakibat pada martabat manusia sebagai sebuah nilai. ${ }^{26}$

Hak atas hidup (the right to life) diatur dalam Pasal 11. Bersama-sama dengan human dignity, the right to life ini oleh Mahkamah Konstitusi Afrika Selatan dikatakan sebagai 'the most important of all human rights' dan 'the ultimate limitation of state power'. ${ }^{27}$ Hak atas kebebasan dan keamanan individu dijamin oleh Pasal 12, yang juga meliputi beberapa hak, antara lain: hak untuk tidak ditahan tanpa diadili; bebas dari segala macam bentuk kekerasan; hak tidak dihukum secara kejam dan tidak manusiawi; dan hak membuat keputusan berkenaan dengan reproduksi. Pasal 13 menjamin bahwa seseorang mempunyai hak untuk tidak diperbudak ataupun kerja paksa, sedangkan Pasal 14 memberikan jaminan atas privasi.

Selanjutnya, Pasal 15 memberikan jaminan atas kebebasan beragama, kepercayaan, dan berpendapat. Hak untuk berekspresi dijamin dalam Pasal 16, yang antara lain meliputi kebebasan pers dan media lain, kebebasan menerima informasi, kebebasan akademik dan kebebasan melakukan penelitian ilmiah. Namun demikian, kebebasan yang diatur dalam Pasal 16 tersebut tidak termasuk propaganda perang ataupun ujaran kebencian.

Pasal 17 menjamin hak untuk berkumpul, berdemonstrasi, dan menyampaikan petisi yang diikuti oleh jaminan untuk berorganisasi dalam Pasal 18. Hak-hak politik yang meliputi hak membentuk partai politik, hak memberikan suara, berkampanye atas nama partai politik, dan lain-lain diatur dalam Pasal 19. Pasal 20 mengatur hak

25 Ibid., hlm. 362.

26 Ibid.

27 Ibid. 
atas kewarganegaraan. Selanjutnya, Pasal 21 menjamin hak untuk bergerak dan bertempat tinggal, termasuk didalamnya hak untuk mempunyai paspor. Hak memilih pekerjaan dan profesi dijamin oleh Pasal 22, sedangkan hak-hak pekerja diatur dalam Pasal 23 (termasuk didalamnya hak untuk mogok dan memilih serikat pekerja).

Hak atas lingkungan hidup yang sehat yang dikategorikan sebagai HAM generasi ketiga dijamin oleh Pasal 24. Pasal 25 menjamin hak milik. Hak-hak ekonomi dan sosial dijamin oleh Pasal 26 dan 27, meliputi hak atas perumahan yang layak, hak atas pelayanan kesehatan (termasuk pelayanan berkenaan dengan reproduksi), hak atas jaminan sosial, serta hak atas pangan dan air. Hak-hak anak secara spesifik dijamin oleh Pasal 28 yang meliputi, antara lain: hak mempunyai nama dan kewarganegaraan sejak lahir, hak atas nutrisi dasar, pelayanan dasar kesehatan serta pelayanan sosial, hak untuk dilindungi dari praktik eksploitasi tenaga kerja, dan lain-lain. Pasal 29, 30, dan 31 menjamin hak-hak berkenaan dengan budaya, bahasa, dan pendidikan. Selanjutnya, Pasal 32 mengatur hak atas akses informasi dan administrasi peradilan. Akses ke pengadilan sebagai HAM dijamin oleh Pasal 34, sedangkan Pasal 35 mengatur hak-hak orang yang ditangkap, ditahan, dan hak-hak sebagai terdakwa.

Sebagaimana disebutkan dalam Pendahuluan, Australia merupakan salah satu negara yang tidak memiliki Bill of Rights yang tercantum dalam Konstitusi 1900. Namun demikian, ketentuan-ketentuan internasional HAM memiliki akibat politik dan hukum di Australia. ${ }^{28}$ Secara politik, ketentuan-ketentuan hukum internasional digunakan secara luas dalam perdebatan-perdebatan mengenai hak-hak atas anak, euthanasia, serta mandatory sentencing. ${ }^{29}$ Secara hukum, ketentuan-ketentuan hukum internasional diterapkan oleh para hakim, terutama di Mahkamah Agung, melalui konstruksi terhadap undang-undang (the construction of statutes), ${ }^{30}$ perkembangan common law (the development of the common law), ${ }^{31}$ putusan pejabat administrasi negara (administrative decision-making), ${ }^{32}$ dan penafsiran undang-undang dasar (constitutional interpretation). ${ }^{33}$

Salah satu akibat hukum pengaturan hak asasi manusia dalam konstitusi yaitu meletakkan kewajiban bagi negara atau pemerintah untuk melakukan peng-

28 George Williams, "The Australian Constitution and Human Rights: A Centenary View", hlm. 5, https://openresearch-repository.anu.edu.au/bitstream/1885/42078/2/Williams.pdf, diunduh 20 Maret 2017.

29 Ibid.

30 Misalnya, Chu Kheng Lim v Minister for Immigration (1992) 176 CLR 1 at 38 (Brennan, Deane and Dawson JJ).

31 Misalnya, Mabov Queensland [No 2] (1992) 175 CLR 1 at 42 (Brennan J).

32 Lihat Minister for Immigration and Ethnic Affairs v Teoh (1995) 183 CLR 273.

33 Misalnya, Newcrest Mining (WA) Ltd v Commonwealth (1997) 190 CLR 513 at 657-8 (Kirby J). Kirby menyatakan: "To the full extent that its text permits, Australia's Constitution, as the fundamental law of government in this country, accommodates itself to international law, including in so far as that law expresses basic rights". George Williams, Loc. cit. 
hormatan (obligation to respect), melakukan perlindungan (obligation to protect), serta mengambil segala tindakan yang diperlukan untuk mencapai pemenuhan hak asasi tersebut (obligation to fulfill). Kewajiban melakukan penghormatan membawa negara atau pemerintah tidak dapat secara sewenang-wenang mencampuri baik secara langsung maupun tidak langsung, seperti misalnya berkenaan dengan hak atas pendidikan.

Kewajiban menghormati menyebabkan negara atau pemerintah dilarang melakukan tindakan yang menghalang-halangi pelaksanaan hak atas pendidikan. Kewajiban melakukan proteksi berarti negara atau pemerintah harus mengambil langkah-langkah atau tindakan-tindakan yang mencegah pihak ketiga melakukan pelanggaran, seperti membiarkan pihak swasta menerapkan ketentuan uang sekolah yang sangat tinggi. Sedangkan kewajiban melakukan pemenuhan mengharuskan negara atau pemerintah melakukan tindakan-tindakan tertentu agar hak mendapatkan sekolah gratis untuk tingkat pendidikan dasar dapat dinikmati oleh semua orang.

Dalam praktik, sering dinyatakan bahwa pemenuhan hak-hak sipil dan politik lebih mudah dilakukan karena bersifat justiciable. Hal ini dikarenakan hak-hak sipil dan politik bersifat absolut dan dapat diimplementasikan dengan segera. Oleh karenanya hak-hak tersebut justiciable dalam arti "they can be employed as the basis for judicial decision, and they are the subject of the most effective international monitoring procedures". ${ }^{34}$ Sebaliknya, hak-hak ekonomi, sosial, budaya serta hak-hal solidaritas relatif lebih sulit karena bersifat non-justiciable. Realisasi hak-hak tersebut semata-mata dilakukan secara bertahap sebagaimana dinyatakan dalam Pasal 2 Kovenan Internasional Hak-Hak Ekonomi, Sosial, dan Budaya yang berbunyi:

"to take steps individually and through international assistance and cooperation, especially economic and technical, to the maximum of its available resources, with a view to achieving progressively the full realisation of the rights recognized in the present Covenant by all appropriate means, including particularly the adoption of legislative measures."

Akibatnya, hak-hak tersebut tidak dapat dituntut pemenuhannya melalui pengadilan atau badan-badan sejenis. ${ }^{35}$ Perbedaan ketiga jenis hak asasi tersebut didasarkan pada karakteristik (nature) di mana disebutkan bahwa hak-hak sipil dan politik merupakan hak-hak negatif (negative rights) dalam arti negara atau

34 Gudmundur Alfredsson, "The Usefulness of Human Rights for Democracy and Good Governance" dalam buku Human Rights and Good Governance: Building Bridges, yang disusun oleh Hans-Otto Sano dan Gudmundur Alfredsson (eds), The Hague, London, New York: Martinus Nijhoff Publishers, 2002, hlm. 20.

35 Asbjørn Eide, "Economic and Social Rights" dalam buku Human Rights: Concept and Standards, yang disusun oleh Janusz Symonides (eds), Aldershot: Ashgate and Unesco Publishing, 2000, hlm. 112. 
pemerintah dilarang mencampuri. Sebaliknya, hak-hak ekonomi, sosial, dan budaya serta hak-hak solidaritas adalah hak-hak positif (positive rights) yang menghendaki campur tangan negara atau pemerintah. Ida Elizabeth Koch menggambarkannya sebagai "if-so formula' meaning 'if certain conditions are fulfilled, a certain legal consequence is to occur or must occur'. ${ }^{36}$ The economic, social and cultural rights usually follow a 'means and end formula'". ${ }^{37}$

Sebagaimana disebutkan di atas bahwa perbedaan karakteristik hak-hak tersebut berkaitan dengan isu justiciability. Namun, Asbjørn Eide beragumen bahwa hak-hak ekonomi, sosial, budaya dan hak-hak solidaritas juga bersifat justiciable:

"First, many aspects of economic and social rights can be made justiciable, as can be seen in many domestic legal systems. Second, the concept of justiciability is in itself very fluid and reflects differences in legal traditions and in philosophical views about the relationship between courts and the state. Third, human rights can still be human rights even when they are not in all aspects justiciable. Compliance with the corresponding obligations can be monitored nationally and by international bodies...Furthermore, rights which are not initially justiciable can gradually become so by concretization both through practice and through more detailed standard-setting at the international level and by legislation at the national level." ${ }^{38}$

Justiciability hak-hak ekonomi, sosial, dan budaya telah diperlihatkan dalam praktik di beberapa negara. Di Afrika Selatan, misalnya, Pemerintah diminta memenuhi hak atas perumahan yang layak (the right to adequate housing) melalui putusan Mahkamah Konstitusi dalam perkara Government of the Republic of South Africa and others $v$ Grootboom and others (2001 (4) SA 46 (CC). ${ }^{39}$ India menjadi salah satu contoh menarik dalam pemenuhan hak atas pendidikan (the right to education) berkat 'intervensi' badan pengadilan melalui mekanisme Public Interest Litigation (PIL), melalui putusan dalam perkara Mohini Jain v State of Karnataka dan Unni Khrisnan J.P v State of Andhra Pradesh. ${ }^{40}$ Dalam putusan pada perkara Unni Khrishnan J.P v State of Andhra Pradesh, Mahkamah Agung secara tegas menyatakan bahwa hak yang tercantum dalam Directive Principles memiliki fungsi penting dalam kepemerintahan dan bersifat instrumental saat pengadilan

36 Ida Elisabeth Koch, "Good Governance and Implementation of Economic, Social and Cultural Rights" dalam Hans-Otto Sano dan Gudmundur Alfredsson (eds), Op.cit., hlm 76.

37 Ibid.

38 Asbjørn Eide, Op., cit, hlm 112-113.

39 Ringkasan perkara Grootboom dapat dibaca dalam Elisabeth Wickeri, “Grootboom's Legacy: Securing the Right to Access to Adequate Housing in South Africa?", Working Paper Economic, Social and Cultural Rights Series, Center For Human Rights and Global Justice, Number 5, 2004.

40 Vijayashi Sripati dan Arun K. Thiruvengadam, "Constitutional amendment making he right to education a Fundamental Rights", Int J Constitutional Law, 2004, hlm. 152. 
menafsirkan isi hak-hak fundamental. ${ }^{41}$ Salah satu efek langsung putusan perkara Unni Khrisnan tersebut, setiap anak yang berusia di bawah 14 tahun dan hak atas pendidikan mereka tidak dipenuhi, dapat meminta writ of mandamus dari pengadilan untuk memerintahkan pejabat yang berwenang melakukan tindakantindakan tertentu. ${ }^{42}$

\section{UUD 1945 dan Hak Asasi Manusia}

Setiap kali ada diskursus atau tulisan mengenai hak asasi dalam UUD 1945 hampir selalu dikembalikan pada perbedaan pandangan antara Supomo-Soekarno di satu pihak dan Hatta-Yamin di pihak lain. Ada diskursus atau tulisan seolah-olah Supomo-Soekarno menolak hak asasi karena berakar pada liberalismeindividualisme. Di pihak lain, Hatta-Yamin membela hak asasi dengan alasan tidak bertentangan dengan paham kekeluargaan.

Sebetulnya, bukan eksistensi hak asasi yang menjadi pokok perbedaan pendapat, melainkan "apakah hak asasi mesti menjadi muatan UUD?" SupomoSoekarno berpendirian, hak asasi tidak tepat menjadi materi muatan UUD, karena UUD Indonesia merdeka berdasarkan asas kekeluargaan, bukan liberalismeindividualisme. Hatta sependirian, menolak liberalisme-individualisme dan menerima dasar kekeluargaan. Tetapi menurut Hatta, asas kekeluargaan atau kolektivisme memberi tempat hak asasi tertentu seperti hak 'mengeluarkan perasaannya' (hak berpendapat). Selain itu, Hatta menyatakan jangan sampai negara baru (Indonesia merdeka) menjadi 'negara kekuasaan'. Hatta mengakui tidak semua ketentuan 'Declaration de l'Homme et du Citoyen' Perancis (1791) perlu dimuat dalam UUD Indonesia merdeka.

Ada 2 (dua) hal ketentuan yang berkaitan dengan hak asasi dalam UUD yang disahkan tanggal 18 Agustus 1945. Pertama, hak asasi yang secara eksplisit dimuat sebagai kaidah konstitusi (individual), yaitu Pasal 27 (persamaan di depan hukum, hak atas pekerjaan dan penghidupan yang layak), Pasal 29 (kebebasan beragama dan menjalankan ibadah menurut agama dan kepercayaan), serta Pasal 31 (hak memperoleh pengajaran). Bahkan UUD telah menentukan hak-hak asasi ekonomi dan sosial sebagaimana diatur dalam Pasal 33 dan Pasal 34. Kedua, UUD memerintahkan "hak atas kemerdekaan berserikat dan berkumpul, mengeluarkan pikiran ... dan lain-lain" diatur dengan undang-undang (Pasal 28). Jaminan Pasal 28 termasuk jaminan yang 'implied' karena itu serta merta diterima oleh Hatta.

Di sisi lain, terdapat catatan mengenai Pasal 28 UUD 1945. Menurut teknik perundang-undangan, pasal ini lazim digolongkan sebagai 'pasal penunjuk' yang memerintahkan dibentuk undang-undang organik. Ada 2 (dua) pandangan

$41 \quad$ lbid., hlm. 153.

42 Ibid. 
terhadap pasal penunjuk ini. Pertama, pendapat yang mengatakan bahwa karena masih akan atau harus diatur dengan undang-undang, berarti UUD 1945 belum menjamin hak berapat, berkumpul, dan menyatakan pendapat. Kedua, pendapat yang menyatakan, secara asasi UUD 1945 telah menjamin hak berapat, berkumpul, dan menyatakan pendapat bahwa sebagai suatu ketentuan yang implied, tidak mungkin pembentuk undang-undang membuat ketentuan yang tidak menjamin hak berapat, berkumpul, dan menyatakan pendapat. Selain itu, perlu juga ditegaskan, perintah Pasal 28 tidak harus diatur dalam satu undang-undang tentang hak berapat, berkumpul dan menyatakan pendapat, melainkan berbagai undang-undang seperti undang-undang kepartaian, dan undang-undang pemilihan umum. (huruf tebal oleh Tim Penulis)

Walaupun UUD 1945 tidak memuat rincian hak asasi seperti 'Droit de l'Homme et du Citoyen', tetapi selama periode pertama UUD 1945, hak asasi berjalan sebagaimana mestinya. Pihak pemerintah mengeluarkan Maklumat Pemerintah tanggal 14 November 1945 yang berisi, antara lain:

"Untuk mendorong dan memajukan tumbuhnya pikiran-pikiran, maka

Pemerintah RI menganjurkan kepada rakyat untuk mendirikan partaipartai guna mewakili segala pikiran politik dalam negara. Bibit-bibit dari beberapa partai itu sudah tumbuh sebelum penjajahan Jepang, akan tetapi terpaksa tidak menampakkan diri dalam zaman pemerintahan Jepang disini."

Selain kebebasan mendirikan partai politik, juga didapati kebebasan mendirikan organisasi pemuda (misal Gerakan Pemuda Islam Indonesia/GPII dan Pemuda Sosialis), mahasiswa (misal Himpunan Mahasiswa Islam/HMI), serta organisasi wartawan (Persatuan Wartawan Indonesia/PWI). Kebebasan pers dijamin dan berjalan sebagaimana mestinya.

Keadaan berubah ketika UUD 1945 berlaku kembali. Di masa Orde Lama, atas nama 'Revolusi belum selesai' dan 'menghadapi neo-kolonialisme dan neoimperealisme', berbagai kebebasan sangat dibatasi. Terdapat partai-partai politik yang dinyatakan sebagai organisasi terlarang atau penahanan tanpa diadili. Pers setiap saat terkena breidel dan sensor, bahkan dicabut hak untuk terbit. Di masa Orde Baru, atas nama pembangunan cq pembangunan ekonomi, pembatasanpembatasan kebebasan berlanjut. Selain itu, terjadi pengelompokan kembali partai politik yang menghasilkan Sekretariat Bersama Golongan Karya (Sekber Golkar), Partai Demokrasi Indonesia (PDI), dan Partai Persatuan Pembangunan (P3). Di sisi partai politik, terdapat larangan orang tertentu memimpin partai, sedangkan di sisi lain, pers tidak hanya menghadapi ancaman breidel dan sensor, namun juga diwajibkan mempunyai Surat Izin Usaha Penerbita (SIUP) yang sewaktu-waktu dapat dicabut. 
Dalam perjalanan bernegara dan berbangsa, pernah berlaku KRIS (1949-1950) dan UUDS 1950 (1950-1959). KRIS adalah konstitusi federal sebagai salah satu hasil Konferensi Meja Bundar yang memuat ketentuan hak asasi yang rinci. Selain karena ada tuntutan terkait kekhawatiran kekejian kemanusiaan (tragedi kemanusiaan) seperti yang terjadi menjelang dan selama Perang Dunia Kedua, rincian hak asasi dalam KRIS tidak terlepas dari pengaruh Universal Declaration of Human Rights yang diadopsi pada tanggal 10 Desember 1948. Deklarasi ini belum ada pada saat penyusunan UUD 1945. Sumber-sumber ketentuan yang populer pada tahun 1945 terutama Magna Carta (Ingris, 1215), Declaration de l'Homme et du Citoyen (Perancis, 1791), Bill of Rights (Inggris, 1688), Virginia Bill of Rights (1776), The Ten Amandements (Bill Of Right Amendments) UUD Amerika Serikat (1791).

UUDS 1950 secara hukum disebut sebagai 'perubahan KRIS', bukan penggantian atau pembentukan UUD baru, meskipun dalam realitas UUDS 1950 adalah UUD tentang susunan baru RI karena kembali kepada negara kesatuan. Prosedur perubahan ini 'diketemukan' berdasarkan Mosi Integral Mohammad Natsir (Ketua Fraksi Partai Masyumi di Dewan Perwakilan Rakyat-RIS). Ada dua prinsip sebagai pedoman perubahan KRIS menjadi UUDS 1950. Pertama, kesepakatan 'hanya' meniadakan ketentuan-ketentuan yang bersifat federalistik. Ketentuan-ketentuan hak asasi bukan unsur yang bersifat federalistik, karena itu tetap dipertahankan sebagai ketentuan UUDS 1950. Kedua, kesepakatan yang dibuat antara Pemerintah RIS dan Pemerintah RI Yogyakarta menyetujui dimasukkannya prinsip-prinsip dasar yang didapati dalam UUD 1945, seperti prinsip demokrasi ekonomi.

Pada awalnya, hak asasi berdasarkan KRIS dan UUDS 1950 berjalan dengan baik seperti suasana terdahulu. Pengekangan mulai terjadi (di masa UUDS 1950) sejak Pemerintah menyatakan 'keadaan darurat'. Keadaan darurat berlangsung lama dan baru diakhiri tahun 1963 (di masa UUD 1945). Reformasi memulihkan berbagai hak asasi melalui perubahan UUD 1945, Ketetapan MPR, serta Undang-Undang. Namun demikian, kebebasan yang dinikmati sejak reformasi lebih banyak berkaitan dengan kebebasan individu dan politik. Hak asasi di bidang sosial dan ekonomi masih sekedar cita-cita, bahkan ada yang berpendapat, jurang antara kaya-miskin makin menajam. Apapun data statistik atau trend yang menunjukkan keberhasilan pembangunan, namun kemiskinan dan ketidakadilan sosial masih menjadi kenyataan. Perlu kesadaran bahwa semua ini bukanlah soal anggaran, melainkan persoalan mismanagement, maladministration, ketiadaan tanggung jawab, serta rendahnya nilai-nilai kemanusiaan. Ini merupakan penyakit luar biasa yang menghinggapi penyelenggara negara dan pemerintahan, termasuk siapa saja yang mempunyai hubungan dengan kekuasaan. 


\section{E. Penutup}

Menutup artikel ini, menarik memahami 2 (dua) 'cautionary observation' yang disampaikan oleh Hakim Amerika Serikat dan salah satu perancang Konstitusi India. ${ }^{43}$ Dalam pidato 'The Spirit of Liberty' yang disampaikan pada tahun 1944, Judge Learned Hand menyatakan:

"Liberty lies in the hearts of men and women; when it dies there, no constitution, no law, no court can save it; no constitution, no law, no court, can even do much to help it. While it lies there it needs no constitution, no law, no court to save it."

Observasi kedua disampaikan oleh Dr. BK Ambedkar, Ketua Komite Perancang Konstitusi pada The Constituent Assembly yang merancang Konstitusi India. Pada tanggal 25 November 1949, sehari sebelum Rancangan Konstitusi India diterima dan disahkan, Ambedkar berkata:

"I feel however good a Constitution may be, it is sure to turn out bad because those who are called to work it, happen to be a bad lot. However bad a Constitution may be, it may turn out to be good if those who are called to work it, happen to be a good lot."

Kedua pidato tersebut memperlihatkan pentingnya budaya menghormati HAM dan kebebasan dalam suatu masyarakat. Persoalannya, sejauh mana budaya tersebut didukung serta dilindungi oleh hukum dan peraturan perundangundangan?

Konstitusi adalah 'the supreme law of the land'. Memasukkan hak-hak asasi dalam konstitusi tidak saja menegaskan hak asasi sebagai fundamental rights, melainkan sekaligus sebagai 'the supreme constitutional rights'. Hal ini juga membawa konsekuensi bagi negara terhadap 3 (tiga) kewajiban dasar yaitu kewajiban melakukan penghormatan, perlindungan, dan pemenuhan hak-hak tersebut. Proteksi konstitusional terhadap HAM hanya dapat berperan penting jika setiap orang yang memperoleh perlindungan melalui konstitusi dan peraturan perundang-undangan serta mereka yang melaksanakan kewenangan berdasarkan konstitusi dan peraturan perundang-undangan mempunyai 'keterikatan' terhadap berbagai HAM tersebut.

\section{Daftar Pustaka \\ Buku}

Bagir Manan, Teori dan Politik Konstitusi, Yogyakarta, FH UII Press, 2002.

43 Robert French, "The Constitution and the Protection of Human Rights", Edith Cowan University ViceChancellor's Oration, Perth, 20 November 2009, hlm. 33, http://www.hcourt.gov.au/assets/publications/ speeches/current-justices/frenchci/frenchcj20nov09.pdf, diunduh 19 Maret 2017. 
dan Susi Dwi Harijanti, Memahami Konstitusi: Makna dan Aktualisasi, Jakarta, Rajagrafindo Persada, 2014.

Bellamy, Richard dan Alex Warleigh, (eds), Citizenship and Governance in the European Union, London, New York: Continuum, 2001.

Currie, lain dan Johan de Waal (eds), The New Constitutional \& Administrative Law, Lansdowne, Juta Academic, 2001.

Jackson, Vicky C. dan Mark Tushnet, Comparative Constitutional Law, New York, Foundation Press, 1999.

Lindsey, Tim (eds), Indonesia: Law and Society, $2^{\text {nd }}$ edition, The Federation Press, Annandale NSW, 2008.

Morris, Clarence (eds), The Great Legal Philosophers, Philadelphia, The University of Pennsylvania, 1979.

Sano, Hans-Otto dan Gudmundur Alfredsson (eds), Human Rights and Good Governance: Building Bridges, The Hague, London, New York, Martinus Nijhoff Publishers, 2002.

Strong, C. F., Modern Political Constitution, London, Sidgwick \& Jackson, 1966.

Symonides, Janusz (eds), Human Rights: Concept and Standards, Ashgate and Unesco Publishing, Aldershot, 2000.

Wheare, K. C., Modern Constitution, Oxford, Oxford University Press, 1960.

\section{Dokumen Lain}

Atip Latipulhayat, "Editorial: Pengarusutamaan Pelayanan Publik sebagai HAM", Padjadjaran Jurnal IImu Hukum, Vol. 1, No. 2, 2014.

French, Robert, "The Constitution and the Protection of Human Rights", Edith Cowan University Vice-Chancellor's Oration, Perth, 20 November 2009, http://www.hcourt.gov.au/assets/publications/speeches/current-justices/ frenchcj/frenchcj20nov09.pdf, diunduh 20 Maret 2017.

Elisabeth Wickeri, "Grootboom's Legacy: Securing the Right to Access to Adequate Housing in South Africa?", Working Paper Economic, Social and Cultural Rights Series, Center For Human Rights and Global Justice, Number 5, 2004.

Michelman, Frank I., "The constitution, social rights, and liberal political justification", I.CON, Vol. 1, No. 1, 2003.

Sripati, Vijayashi dan Arun K. Thiruvengadam, "Constitutional amendment making he right to education a Fundamental Rights", Int J Constitutional Law, 2004.

Wikipedia, "Rerum Novarum", https://en.wikipedia.org/wiki/Rerum novarum, diakses 20 Maret 2017.

Williams, George, "The Australian Constitution and Human Rights: A Centenary View",https://openresearch-repository.anu.edu.au/bitstream/ 1885/42078/2/Williams.pdf, diunduh 20 Maret 2017. 


\section{Dokumen Hukum}

Konstitusi Amerika Serikat 1787.

Konstitusi Australia 1901.

Undang-Undang Dasar Indonesia 1945.

Konstitusi India 1949.

Konstitusi Republik Indonesia Serikat 1949.

Undang-Undang Dasar Sementara 1950.

Konstitusi Afrika Selatan 1996.

Konstitusi Filipina 1987.

Chu Kheng Lim v Minister for Immigration (1992) 176 CLR 1.

Mabo v Queensland [No 2] (1992) 175 CLR 1.

Mohini Jain v State of Karnataka A.I.R (1992) S.C. 1858.

Unni Khrisnan J.P v State of Andhra Pradesh A.I.R (1993) S.C. 2178.

Minister for Immigration and Ethnic Affairs v Teoh (1995) 183 CLR 273.

Newcrest Mining (WA) Ltd v Commonwealth (1997) 190 CLR 513.

Government of the Republic of South Africa and others $v$ Grootboom and others (2001 (4) SA 46 (CC). 